\title{
Promoting Reading Interest among Hospitalized Children with Cancer: Sharing Experience of Society Advancement of Children Literature's Bibliotherapy Program in a Public Hospital
}

\author{
Ida Farida \\ Department of Library \& \\ Information Science \\ Syarif Hidayatullah \\ State Islamic University (UIN) \\ Jakarta, Indonesia \\ ida_farida@uinjkt.ac.id
}

\author{
Lisma Dyawati Fuaida \\ Department of Social Welfare \\ Syarif Hidayatullah \\ State Islamic University (UIN) \\ Jakarta, Indonesia \\ lisma.fuaida@uinjkt.ac.id
}

\author{
Pungki Purnomo \\ Department of Library \& \\ Information Science \\ Syarif Hidayatullah \\ State Islamic University (UIN) Jakarta, \\ Indonesia \\ pungki.purnomo@uinjkt.ac.id
}

\begin{abstract}
This paper attempts to explore the practice of bibliotherapy program carried out by a non government organization, SACL (Society Advancement of Children Literature), in providing bibliotherapy program for children with cancer in a large public hospital at Rumah Sakit Cipto Mangunkusumo (RSCM). Children with cancer usually stay long in hospital to receive intensive medical treatment. SACL, is an organization which concerns with promoting reading interest started the program in 1993. Children who are sick have the same opportunity to enjoy reading as much right as the healthy children do that is the philosophy of the program. Unlike healthy children, children with cancer usually have physical limitation to access to reading materials and library. A case study approach used to gather data relating to this program. The discussion covers on how SACL organize the program routinely every Saturday for 24 years and special needs of children with cancer to enjoy reading books. The significance of the study gives insight to others about the best practice of Non Governmental Organization (NGO) at community level in providing a service for hospitalized children with cancer.
\end{abstract}

Keywords: Bibliotherapy, reading interest, hospitalized children, children with cancer, disability

\section{INTRODUCTION}

Children everywhere in the world have the same right to develop his or her full potential, to get free and open access to information, materials, and programs irrespective of their different condition [1]. This convention of the United Nations has guaranteed the right children with disabilities to have equal service like other children without disabilities. Recently, Indonesian government has issued a decree number 8 in 2016 regarding the right of individual with disabilities including the children. According to this decree a person with disability is anyone with long-term physical, intellectual, mental, and /or sensory limitations who interact with the environment may experience barriers and difficulties to participate fully and effectively with other citizens on the basis of equal rights [2]. This decree also emphasize to give opportunities and/or to provide access to person with disabilities so that they can channel their potential in all aspect for the country and the community.

Observing to the definition of the decree, majority hospitalized children with cancer are included into the people with disability. Because of intensive medical treatment, such as bone-marrow biopsies, chemotherapy, blood test, surgery and etc. Many of them need to stay in hospital for long time. A study carried out by Moody and Mancuso observed that children who received cancer therapy encountered physical discomfort such as nausea, pain and disability. Beside that they were also unable to have a normal childhood like participate in everyday life activities and socialization which caused them having lonely and isolated feeling. They experienced emotional response to cancer; fear and anger and decreased pleasure from food [3]. 
According to Schneider, Peterson, Gathercoal \& Hamilton, hospitalized children with cancer generally have high anxiety because they cannot manage well their stressors that are ongoing medical procedures to cure their health condition problems. Children's cognitive skills developments that relate with coping to those stressors are also still lacking [4].

SACL (Society Advancement of Children Literature) or Kelompok Pencinta Bacaan Anak (KPBA) is a nonprofit organization founded by Dr. Murti Bunanta in 1987. The organization's purpose is to develop and nurture children literature in Indonesia through various programs in order to enhance children's reading interest, quality of children books and library service [5]. In 1993, SACL started the program of bibliotherapy. The term of bibliotherapy used by SACL refers to the utilization of children's books and other media for telling stories by SACL's volunteers as an intervention to help hospitalized children with cancer forget for a while their sickness and pain during the program in order to reduce their stress and anxiety [6].

Ideally, the bibliotherapy program involves selecting thematic books or reading materials appropriate with children's situation. The reading materials must be suitable with child's reading level and fulfill the child's emotional and developmental needs [7]. When read the book with the help of adult or read alone, the child will be going through the process of identification, carthasis, and insight. He or she learn to identify the main character and the event from the reading material, relate the story to their condition and get the attachment feeling to the character and finally get insight to allow reader understand his or her problems that he or she attempts to deal with [8].

However, the practices of bibliotherapy by SACL's volunteers are not yet very rigidly follow the practice of bibliotherapy by using appropriate book theme with child's need that is cancer theme. So far, the volunteers do not find the book with cancer theme publish in Indonesia. SACL's volunteer read the book with various themes regularly for the past 24 years, every Saturday.

One of the rights of individual with disabilities is the right to get information, one of the services regarding to it is the availability of library service for them. As the children with cancer has physical limitation to come to the library or any programs related to books'promotion. SACL offers an outreach program of bibliotherapy for them. This paper attempts to understand how SACL provide a bibliotherapy service for hospitalized children with cancer.

\section{METHODS}

This study used single case study approach to gather information about the activities of bibliotherapy of SACL. This method allowed the researcher to explore the phenomenon of SACL's bibliotherapy program for hospitalized children with cancer using a variety of data sources, such as reports of volunteers, interviews of volunteers, website of SACL, conference papers and observations of volunteers during bibliotherapy program.There are three informants taken from SACL's volunteers who shared their experience during their turn in telling stories for the children. This is descriptive type of a case study which has an intention to describe a phenomenon in which it occurred [9]. Based on various information gathered from different sources, coding process were employed to build categories and themes in order to explain the bibliotherapy program of SACL.

\section{RESULT AND DISCUSSION}

The result and discussion of this study are arranged based on themes coming up from research data analysis that covers bibliotherapy activities, books collection and other media for bibliotherapy, follow-up activities of biblioitherapy, reading interest among hospitalized children with cancer, and lessoned learned from bibliotherapy programs.

\section{A. Bibliotherapy Activities}

A group of volunteers from SACL members are organized into 1-3 people to come every Saturday. Every person will carry their book collection or from SACL's collection. The themes of book are related with the age of children. The volunteer will come from bed to bed to offer reading the books and telling stories. When the child or the adult who take care the child agree then the volunteers will ask the children to choose the books that he or she brought in the bag. Sometimes children from two beds can enjoy bibliotherapy time together or children in a row of bed. When one room of children wants to hear story together, then the bibliotherapy set up for all. Some children are liked to read by her parents or read independently.

\section{B. Books Collection and Other Media for Bibliotherapy}

Books that used for bibliotherapy are mainly picture books, books with illustrations. The picture books attract the interest for the children. According to Pardeck, picture book can facilitate the process of bibliotherapy [10]. Children pay attention to the illustration and the color of it. As the volunteer read aloud the books the children enjoy the visual art of picture book. Volunteers often see that children love to see the pictures of the book while it was read by them. Every volunteer is usually having the list of favorite's books collection they love to read aloud for children. Besides books volunteers used other media for telling stories such as origami papers, string and puppets.

\section{Follow-up Activities of Bibliotherapy}

Besides reading the books and telling stories, the volunteers offer other activities such as making origami and colouring. These activities may relate to the stories or apart from the stories. When the hands of children are free from medical 
treatment, he or she can make origami by himelf or herself. He or she also can coloring a picture on a piece of paper, the colour pencils brought by volunteers. When the children cannot move his or hand the parents will join the activities. Children pay attention to the process of making origami, the result will be given to them.

\section{Reading Interest among Hospitalized Children with Cancer}

Even though, children are suffering in the process of medical treatment in fighting the cancer, many of them welcome the volunteers to read and telling the stories. They enjoy listening the story using different media and happy seeing good illustration in picture books. They can forget for a while their pain during bibliotherapy session. Some of the children are able to participate actively in the story. Some of them love to read independently. Some of them love to borrow the books and asked their mother or father to read the books for them.

The program has been carried out for 24 years. Many children usually waits the volunteers, they are ready to listen to the story. Even the doctors and medical staffs know the program. Nurses are doing their task like injecting the medicine during the child pays attention to the story. Doctor waits the volunteer in telling story to diagnose the child; he or she will diagnose other children while waiting the volunteers completing the story. Those are the phenomena in bibliotherapy session. Besides the children who enjoy the reading, parents or people whom taking care to the children also show interest in listening to the story and take a part in bibliotherapy's activities.

\section{E. Lesson Learned from Bibliotherapy Programs}

Unlike telling story to healthy children, delivering story to unhealthy children has several different rules:

\section{1). Respect the Children Choice}

There are several experiences of the volunteers which are good to be shared in offering bibliotherapy program. Volunteers are not always welcome to carry out the bibliotherapy program by the children. These are some of the reasons for their refusal: a) the children are in severe pain. b) the children are playing games on laptops or computer game players. c) They don't know yet the joy of listening to stories. This last reason is one of the frequent reasons often encountered by volunteers. But, even though at first a child may refuse to listen to a story when they are offered it, sometime later he or she will ask the volunteers to read a story again and again for him or her. It usually occurs after the child has seen the joy of storytelling hours among the other patients. Volunteers must remember this rule, volunteers come to share good stories and bring the joy of reading. When children refuse to listen to the story, the volunteers must understand and respect their choice and accept this.

2). Be ready to See Unpleasant Situation
Another rule is that volunteers are expected to be ready mentally in seeing unpleasant situation. Most of the children are in the process of receiving intensive medical treatment to fight cancer and are in pain. Therefore the volunteers have to be prepared themselves to see this unpleasant situation. Rumah Sakit Cipto Mangunkusumo (RSCM) is one of the big state hospitals located in center of Jakarta. It is a hospital where many specialized doctors are available and as a place to seek medical treatment when other local or small hospitals are unable to treat. Volunteers have been informed about the situation that they will see in hospital. Thus, one really needs a brave heart to come to a place where the volunteers will often meet the severe conditions of children who suffer from cancer [11]. Not all SACL members become the volunteers of bibliotherapy program. Some of them have soft heart that they could not stand seeing the children who suffer with cancer.

\section{CONCLUSION}

Bibliotherapy is one of the methods believed to alleviate the anxiety and stress level experienced by children with cancer. Through the program that has been carried out by SACL for 24 years, volunteers have seen benefit of bibliotherapy program to the children with cancer, it help them to love reading and also forget for a while their pain. Hope this paper can contribute for people who care for children with chronic illness and understand their needs and right to have access to the program that are enjoyed by other children.

\section{REFERENCES}

[1] United Nations of Human Rights, "OHCHR Convention on the Rights of the Child.," 1989. [Online]. Available: http//:www.ohchr.org/EN/ProfessionalInterest/Pages/CRC.aspx. a Retrieved Oct, 05 th 2017.

[2] Indonesia, Undang-Undang tentang penyandang Disabilitas. 2016.

[3] K. Moody and C. A. Mancuso, "Exploring concerns of children with cancer," Support Care Cancer, vol. 14, pp. 960-966, 2006.

[4] N. M. Schneider, M. Peterson, K. A. Gathercoal, and E. Hamilton, "The effect of bibliotherapy on anxiety

in children with cancer," Int. J. Child Health Hum. Dev., vol. 6, no. 3, pp. 337-345, 2013.

[5] KPBA (Kelompok Pencinta Bacaan Anak, "Tentang Kami (KPBA)," 2017. [Online]. Available: http://kpbamurti.org/tentangkami/ Retrieved 10 October 2017.

[6] I. Farida and Elida, T., "Please Tell a Story for Me Again!: Bibliotherapy for hospitalized children with cancer," presented at the Asian Festival of Children's Content, May 17th 2017, Singapore, 2017.

[7] C. V. Lucas, L. Soares, and C. V. Lucas, "children âs psychological well-being Bibliotherapy: A tool to promote children's 
psychological well-being,” J. Poet. Ther. Interdiscip. J. Pract. Theory Res. Educ., no. March 2015, pp. 37-41, 2013.

[8] D. Sridhar, "Bibliotherapy for all," Teach. Except. Child., vol. 33, no. 2, pp. 77-82, 2000.

[9] P. Baxter, and S,Jack, "Qualitative Case Study Methodology: Study Design and Implementation for Novice Researchers," Qual. Rep., vol. 13 , no. 4 , pp. 544-559, 2008.

[10] J. T. Pardeck, "Bibliotherapy : An Innovative Approach for Helping Children," Early Child Dev. Care, vol. 110, no. 1, pp. 83- 88, 1995.

[11] M. Bunanta, and Farida, I, "SACL Volunteers ' Experiences in Raising Their Empathy and Awareness towards Others: Sharing Stories for Hospitalized Children with Cancer," presented at the Asia-Oceania Regional IBBY Congress, May 23rd-26th 2013, Bali, 2013. 